\title{
ANALISIS KELAYAKAN AGROINDUSTRI TAHU DI DESA BALOKANG KECAMATAN BANJAR KOTA BANJAR
}

\author{
SUKMA WIBOWO ${ }^{1 *}$,IWAN SETIAWAN ${ }^{2}$,MUHAMAD NURDIN YUSUF ${ }^{1}$ \\ ${ }^{1}$ Mahasiswa Fakultas Pertanian Universitas Galuh Ciamis \\ ${ }^{2}$ Dosen Fakultas Pertanian Universitas Padjadjaran \\ *Email : wibowo.sukma@yahoo.co.id
}

\begin{abstract}
ABSRTRAK
Tujuan penelitian ini adalah : 1) Besarnya biaya produksi yang di keluarkan oleh agroindustri Tahu di Desa Balokang Kecamatan Banjar Kota Banjar. 2) Besarnya penerimaan dan pendapatan yang di terima oleh agroindustri Tahu di Desa Balokan Kecamatan Banjar. 3) Besarnya nilai R/C agroindustri tahu di Desa Balokang Kecamatan Banjar Kota Banjar. Jenis penelitian ini adalah studi kasus pada agroindustri Tahu di Desa Balokang Kecamatan Banjar Kota Banjar. Teknik penarikan sampel dalam penelitian ini dilakukan dengan cara menganbil total sampling terhadap agroindustri Tahu di Desa Balokang Kecamatan Banjar Kota Banjar. Penelitian dan pembahasan dari sepuluh responden agroindustri Tahu di Desa Balokang Kecamatan Banjar Kota Banjar, maka dapat di tarik kesimpulan sebagai berikut : 1) Besarnya total biaya produksi pada Setiap agroindustri Tahu di desa Balokang Kecamatan Banjar Kota Banjar dalam satu kali proses produksi yaitu Rp 706. 570,96 terdiri dari biaya tetap total $\mathrm{Rp} 17.130,21$ dan biaya variabel total $\mathrm{Rp} 689.440,75.2)$ Besarnya rata-rat penerimaan yang di peroleh agroindustri Tahu di Desa Balokang Kecamaan Banjar Kota Banjar dalam satu kali proses produksi yaitu Rp 1. 265.000,00 Hasi dari produksi rata-rata 2.100 buah per satu kali proses produksi di kalikan dengan harga per satu buah tahu yaitu Rp 350 di tambah ampas tahu per karung Rp 5000. 3) Besarnya nilai R/C agroindustri Tahu di Desa Balokang Kecamatan Banjar Kota banjar yaitu Rp 1,79 artinya nilia R/C lebih dari satu, maka dapat di simpulkan bahwa agroindustri tahu di Desa Balokang Kecamatan Banjar Kota Banjar layak untuk diusahakan.
\end{abstract}

Kata Kunci : Biaya, Penerimaan, Pendapatan, Agroindustri

\section{ABSTRACT}

This study aims to determine: 1) The amount of production costs incurred by the Tofu agro-industry in Balokang Village, Banjar District, Banjar City. 2) The amount of revenue and income received by the Tofu agro-industry in Balokang Village, Banjar District, Banjar City. 3) The amount of R / C value for tofu agroindustry in Balokang Village, Banjar District, Banjar City. This type of research is a case study on Tofu agro-industry in Balokang Village, BanjatrKota Banjar District. The sampling technique in this study was carried out by taking a total sampling of the Tofu agro-industry in Balokang Village, Banjar District, Banjar City. Based on the results of research and discussion of ten respondents tofu agro-industry in Balokang Village, Banjar District, Banjar City, the following conclusions can be drawn: 1) The amount of the total production cost for each tofu agro-industry in Balokang Village, Banjar District, Banjar City in one production process is IDR 706,570 .96 consists of fixed costs totaling Rp. 17. 130.21 and total variable costs Rp. 689,440.75. 2) The average amount of revenue obtained by the tofu agro-industry in Balokang Village, Banjar District, Banjar City in one production process is IDR 1,265,000.00 as a result of the average production of 2,100 pieces per one production process multiplied by the price per one piece. Tofu, which is IDR 350 plus tofu pulp per bag IDR 5,000.3) The amount of $R / C$ value for tofu agroindustry in Balokang Village, Banjar District, Banjar City is IDR 1.79, which means that the $R / C$ value is greater than one, it can be concluded that agroindustry tofu in Balokang Village, Banjar District, Banjar City is worth cultivating.

Keywords: Cost, Revenue, Income, Agroindustry. 


\section{PENDAHULUAN}

Negara Indonesia r yang
merupakan negara agraris yangmana
sebagian besar penduduknya adalah petani.
Pertanian di Indonesia masih megang
peranan penting dari keseluruhan
perekonomian nasional, Dalam hal ini
perkembangan sektor pertanian perlu
mendapat perhatian serius dalam rangka
pembangunan ekonomi nasional

(Partowijoto, 2003)

Produk pertanian umumnya dihasilkan sebagai bahan mentah yang mempunyai sifat mudah rusak dan tidak tahan lama, memerlukan adanya suatu proses pengolahan agar dapat meningkatkan nilai tambah. Oleh karena itu, diperlukan suatu industri pengolahan untuk mengolah hasil pertanian tersebut. Pengolahan hasil pertanian ini bertujuan untuk mengawetkan, menyajikan produk menjadi lebih siap dikonsumsi serta meningkatkan kualitas produk sehingga dapat disajikan dalam bentuk yang lebih baik dan dapat lebih memberikan kepuasan kepada konsumen. Sebagian besar produk pertanian berpotensi untuk ditingkatkan nilainya, sehingga mampu memperoleh harga jual lebih tinggi (Udayana, 2011).

Modal yang relatif kecil dan teknologi yang sederhana menjadikan Industri berbasis kedelai menjadi salah satu Salah satu industri pengolahan yang banyak dijalankan. Kedelai dapat di olah dengan 2 cara, yaitu pengolahan dengan fermentasi dan tanpa fermentasi. Pengolahan dengan fermentasi akan menghasilkan kecap, oncom, tauco, dan tempe. Sedangkan pengolahan tanpa fermentasi berupa tepung kedelai, tauge, tahu, dan susu kedelai. Produk olahan tahu sendiri sudah cukup di kenal di Indonesia Selain harganya yang cukup murah, tahu juga memiliki nilai gizi tinggi (Hadiyanti, 2014).

Industri pengolahan merupakan kegiatan ekonomi yang mengubah suatu barang dasar secara kimia, mekanis, atau dengan tangan sehingga menjadi barang jadi. Barang yang memiliki nilai tambah, dan sifatnya menjadi lebih dekat kepada pemakai akhir. Sektor ini terbukti mampu memberikan kontribusi terbesar dalam Produk Domestik Bruto Nasional. Berdasarkan data BPS Tahun 2013, Kontribusi industri pengolahan terhadap PBD mengalami peningkatan dari tahun 2010 hingga 2012. Pada tahun 2010 industri pengolahan memberikan kontribusi sebesar 1. 599, 073.10 hingga tahun 2012 mencapai 1. 972, 846.60. Hal ini menunjukan bahwa Industri ini pengolahan mampu berkontribusi secara positif terhadap perekonomian nasional. 
Dari tingginya permintaan produk olahan kedelai telah memacu pertumbuhan kebutuhan konsumsi kedelai. Tetapi, peningkatan konsumsi ini tidak diimbangi dengan tingkat produksinya.

Pemerintah memberlakukan impor dari beberapa penghasil kedelai dunia antaralain Amerika serikat, Brazil,

Tabel 1.2. Produksi, impor, kebutuhan dalam negeri, dan pangsa pasar produksi kedelai terhadap kebutuhan dalam negeri tahun 2007 - 2013 (ton)

\begin{tabular}{ccccc}
\hline Tahun & Produksi & Impor & $\begin{array}{c}\text { Kebutuhan Dalam } \\
\text { Negeri }\end{array}$ & $\begin{array}{c}\text { Pangsa produksi terhadap } \\
\text { kebutuhan dalam negeri }\end{array}$ \\
\hline 2007 & 592.534 & 1411589 & 2002251 & 29.59 \\
\hline 2008 & 775710 & 1173097 & 1947782 & 29.59 \\
\hline 2009 & 974512 & 1314620 & 2288686 & 42.58 \\
\hline 2010 & 907031 & 1740505 & 2647151 & 34.26 \\
\hline 2011 & 851286 & 2087986 & 2939272 & 28.96 \\
\hline 2012 & 843153 & 2128763 & 2971976 & 28.37 \\
\hline 2013 & 847157 & 1268543 & 2115700 & 40.04 \\
\hline
\end{tabular}

Kebutuhan kedelai di Indonesia bergantung kepada impor yang cukup tinggi. Hal ini Bisa dilihat pada tabel 2, bahwa kebutuhan kedelai import terhadap konsumsi dalam negeri cenderung meningkat setiap tahunnya.

Ada beberpa Faktor Penyebab Berdasarkan tabel di atas, diantaranya lahan, rendahnya minat petani dalam budidaya kedelai dan pembebasan tarif masuk import (Nurhayat, Wiji 2013). Adapun luas panen kedelai lokal di wilayah Provinsi Jawa Barat adalah sebesar 60.172 ha dan produktivitas 16,44 kwintal per hektarnya. jika dilihat dari sisi geografisnya Jawa Barat cocok
Argentina, Cina, dan India. Data produksi, impor, kebutuhan dalam negri, dan pangsa produksi kedelai terhadap kebutuhan dalam negeri dapat dilihat pada Tabel 2. 
dengan harga Rp 3000 per Kg. Sedangkan untuk kedelai kering yang sudah dikupas harga jual Rp 5000 per Kg. Pangsa pasar dari harga kedelai saat ini berkisar $\mathrm{Rp}$ 8000 per $\mathrm{Kg}$ untuk kedelai import dan Rp 6500 per $\mathrm{Kg}$ untuk kedelai lokal sedangkan harga yang di beli dari petani tetap masih rendah. Sehingga menyebabkan petani enggan untuk menanam kedelai.

Maka dari itu jika hal ini dibiarkan terus menerus akan berdampak terhadap produsen tahu, karena tingginya harga kedelai ini dapat memberatkan pengusaha agroindustri tahu. Salah satu daerah yang banyak mengusahakan agroindustri tahu di Kota Banjar adalah Desa Balokan yang secara administratif berada di wilayah Kecamatan Banjar. Desa Balokan sudah lama ditetapkan sebagai sentra agroindustri tahu oleh Pemerintah Kota Banjar. Data yang diperoleh dari kantor kelurahan setempat terdapat 10 penrajin tahu di Desa Balokang yang masih aktif memproduksi tahu dengan kapasitas produksi berkisar antara 2 sampai 27 ton per tahun dengan nilai produksi sebesar Rp 4.814.000,00 per tahun.

Skala industri tahu yang ada di Desa Balokan masih berbentuk industri rumah tangga sehingga dalam pengolahannya masih bersifat tradisional. Selain itu, keuangan rumah tangga yang biasanya masih bersatu dengan keuangan perusahaan menyebabkan sulit ditentukannya berapa sebenarnya keuntungan yang diperoleh perajin. Bahan baku utama tahu yang dipakai adalah biji kedelai baik lokal maupun impor. Biji kedelai diperoleh perajin di warungwarung dan tengkulak setempat. Sementara untuk pemasarannya, para perajin selain menjual tahu ke pasar tradisional dan masyarakat setempat juga menjual sampai ke luar wilayah Kota Banjar.

Tujuan Penelitian ini untuk mengetahui : 1) Besarnya biaya dan penerimaan agroindustri tahu d Desa Balokang Kecamatan Banjar Kota Banjar. 2) Besarnya Pendapatan agroindustri tahu di Desa Balokang Kecamatan Banjar Kota Banjar. 3) Kelayakan Agroindustri tahu di Desa Balokang Kecamatan Banjar Kota Banjar.

\section{METODE PENELITIAN} Jenis Penelitian

Jenis penelitian yang di gunakan dalam penelitian ini adalah metode survei, dengan mengambil kasus di Desa Balokang Kecamatan Banjar Kota Banjar Menurut (Soekartawi,2016) metode survei adalah "Suatu cara pendekatan dengan mempergunakan teknik yang berhubungan dengan survei". 


\section{Operasionalisasi Variabel}

Variabel yang diamati dalam penelitian ini dioperasionalisasikan sebagai berikut :

1. 1 kali proses produksi adalah dimulai dari penyediaan bahan baku, pengolahan, sampai tahu siap dipasarkan berlangsung selama satu hari.

2. Biaya produksi merupakan korbanan yang dicurahkan dalam proses produksi sehingga menghasilkan produk yang terdiri dari biaya tetap dan biaya variabel.

3. Biaya tetap merupakan biaya yang besarnya tidak di pengaruhi oleh besar kecilnya produksi dan sifatnya tidak habis dipakai dalam satu kali proses produksi yang terdiri dari :

a. Pajak bumi dan bangunan, adalah biaya yang dikeluarkan untuk membayar pajak bumi dan bangunan dalam 1 kali proses produksi yaitu dihitung dalam satuan rupiah ( $R p)$ per satu kali proses produksi.

b. Penyusutan alat, bangunan dapt dihitung dalam satuan rupiah selama satu kali proses produksi. Menurut (Baridwan, 2004) Untuk menghitung besarnya penyusutan alat dan bangunan yaitu dengan digunakan metode garis lurus (Straight line
Methode), dengan menggunakan rumus sebagai berikut :

Penyusutan

$$
=\frac{\text { Nilai Beli }- \text { Nilai Sisa }}{\text { Umur Ekonomis }}
$$

Nilai sisa merupakan nilai pada waktu alat itu sudah tidak dapat digunakan lagi atau dianggap nol.

c. Bunga modal tetap yaitu nilai bunga modal dari biaya tetap yang dihitung berdasarkan bunga bank (bunga pinjaman) yang berlaku pada saat penelitian, dan dinilai dalam satuan rupiah selama satu kali proses produksi.

d. Bunga modal variabel yaitu nilai bunga modal dan biaya variabel yang dihitung berdasarkan bunga bank yang berlaku saat penelitian, dinilai dalam satuan rupiah selama satu kali proses produksi.

4. Biaya variabel yaitu biaya yang besarnya dipengaruhi oleh besar kecilnya produksi yang sifatnya habis pakai dalam satu kali proses produksi, dan termasuk ke dalam biaya variabel adalah :

a. Kacang kedelai dihitung dalam satuan kilogram $(\mathrm{Kg})$ dan dinilai dalam satuan rupiah selama satu kali proses produksi. 
b. Plastik, dihitung dalam satuan pak dan dinilai dalam satuan rupiah selama satu kali proses produksi.

c. Kayu bakar, dihitung dalam satuan ikat dinilai dalam satuan rupiah selama satu kali proses produksi.

d. Cuka, dihitung dalam satuan mg/l dan dinilai dalam satuan rupiah selama satu kali proses produksi.

e. Bahan bakar, dihitung dalam satuan liter dan dinilai dalam satuan rupiah selama satu kali proses produksi.

f. Transportasi, dihitung dalam satuan rupiah, di nilai dalam 1 kali proses.

g. Tenaga kerja, dihitung dalam HOK dan dinilai dalam satuan rupiah dalam 1kali proses.

h. Listrik, dihitung dalam satuan KWH dan dinilai dalam satuan rupiah selama 1kali produksi.

5. Penerimaan yaitu jumlah hasil produksi dikalikan dengan harga jual, dinyatakan dengan satuan rupiah (Rp) per satu kali proses produksi.

a. Hasil produksi dihitung dalam satuan buah

b. Harga jual dihitung dalam satuan rupiah/ buah (Rp/buah)

6. Pendapatan adalah selisih antara penerimaan dengan biaya produksi total yang dinilai dalam satuan rupiah ( $\mathrm{Rp})$ per satu kali proses produksi.
7. $\mathrm{R} / \mathrm{C}$ adalah perbandingan antara penerimaan dengan biaya total.

Dengan asumsi :

a. Teknologi yang digunakan sama

b. Harga input maupun output adalah harga yang berlaku pada saat penelitian.

c. Produk habis terjual.

\section{Teknik Penarikan Sampel}

Desa Balokang diambil secara sengaja (Purposive sampling) dengan pertimbangan karena memiliki agroindustri tahu paling banyak di Kota Banjar Menurut Soekartawi (2016) “Teknik sampling atau teknik / metode pengambilan sampel sering menjadi pertimbangan khusus dalam penelitian".

Teknik penarikan sampel penelitian untuk usaha agroindustri tahu adalah dengan menggunakan total sampling. Artinya seluruh agroindustri tahu di Desa Balokang Kecamatan Banjar di jadikan sampel sebanyak 10 agroindustri. Menurut Arikunto (2006) total sampling adalah pengambilan sampel yang sama dengan jumlah populasi yang ada.

\section{Teknik Pengumpulan Data}

Jenis data yang dikumpulkan dalam penelitian ini meliputi data primer dan data sekunder.

1. Data primer, diperoleh dari responden tahu melalui wawancara langsung 
dengan menggunakan kuesioner sebagai alat bantu yang telah dipersiapkan sebelumnya.

2. Data sekunder, yaitu data yang diperoleh dari hasil pengumpulan orang lain. salah satunya dengan cara studi literatur, yaitu cara pengumpulan data yang dilakukan dengan jalan mempelajari buku-buku, dokumendokumen, dan hasil-hasil penelitian yang berhubungan dengan masalahmasalah yang diteliti.

\section{Rancangan Analisis Data}

Data yang diperoleh akan dianalisis dengan menggunakan metode deskriptif kuantitatif. Untuk mengetahui biaya produksi, penerimaan, pendapatan, dan $\mathrm{R} / \mathrm{C}$ dianalisis menggunakan rumus sebagai berikut :

1. Analisis Biaya

Menurut Soekartawi (2016), untuk menghitung besarnya biaya total (total cost) dapat diperoleh dengan cara menjumlahkan biaya tetap (Fixedcost) dengan biaya variabel (variable cost), dan dihitung dengan rumus :

$\mathbf{T C}=\mathbf{F C}+\mathrm{VC}$

Keterangan :

$\mathrm{TC}=$ Total Cost (biaya total)

$\mathrm{FC}=$ Fixed Cost (biaya tetap)

$\mathrm{VC}=$ Variable Cost (biaya variabel)
2. Analisis penerimaan

Menurut Soekartawi(2016), secara umum perhitungan penerimaan total (Total Revenue/TR) yaitu perkalian antara jumlah produksi (Y) dan harga jual (Hy) dan dihitung dengan rumus sebagai berikut :

$$
\mathbf{T R}=\mathbf{Y} . \mathbf{P y}
$$

Keterangan :

$\mathrm{TR}=$ Total Revenue (penerimaan total)

$\mathrm{Y}=$ Produksi yang diperoleh

Py = Harga

3. Analisis pendapatan

Menurut Soekartawi (2016), pendapatan yaitu selisih antara penerimaan (TR) dan semua biaya total (TC) dan dihitung dengan rumus :

$\mathbf{P d}=\mathbf{T R}-\mathbf{T C}$

Keterangan :

$\mathrm{Pd}=$ Pendapatan

$\mathrm{TR}=$ Total Revenue $($ Penerimaan total $)$

$\mathrm{TC}=$ Total Cost (Biaya total)

4. $\mathrm{R} / \mathrm{C}$

Menurut Soekartawi (2016), R/C yaitu singkatan dari return cost ratio, atau dikenal sebagai perbandingan (nisbah) antara penerimaan dan biaya secara matematik. Perbandingan antara penerimaan dengan biaya, dan dihitung dengan Rumus :

$$
\mathrm{R} / \mathrm{C}=\frac{\text { Total Revenue }(T R)}{\text { Total Cost }(T C)}
$$

Keterangan : 
$\mathrm{R} / \mathrm{C} \quad$ : Revenue Cost Raio $(\mathrm{Rp})$

TR : Penerimaan Total (Rp)

TC : Biaya Total (Rp)

Dengan ketentuan sebagai berikut :

a. $\mathrm{R} / \mathrm{C}<1$, maka usaha tersebut rugi sehingga tidak layak diteruskan.

b. $\mathrm{R} / \mathrm{C}=1$, maka usaha tersebut tidak untung tidak rugi (impas) sehingga tidak layak diteruskan.

c. $\mathrm{R} / \mathrm{C}>1$, maka usaha tersebut untung sehingga layak diteruskan.

\section{Lokasi dan Jadwal Penelitian}

Penelitian dilaksanakan pada Agroindustri tahu di Desa Balokang Kecamatan Banjar Kota Banjar dan pada penelitian ini dilaksanakan melalui beberapa tahap kegiatan sebagai berikut:

1. Survey pendahuluan dan penulisan usulan penelitian dilaksanakan bulan Mei sampai dengan Juni 2019.

2. Kegiatan di lapangan untuk mengumpulkan data, direncanakan pada bulan Januari 2020.

3. Pengolahan data dan pembuatan laporan hasil penelitian, direncanakan pada bulan Januari 2020 sampai dengan selesai.

\section{HASIL DAN PEMBAHASAN Keadaan Daerah Penelitian}

Desa Balokang adalah salah satu Desa yang berada di sebelah Barat wilayah Kecamatan Banjar Kota Banjar Propinsi Jawa Barat. Jarak dari Desa Balokang ke Kecamatan Banjar yaitu 5 Kilometer sedangkan jarak Ibukota Banjar adalah 125 Kilometer, dengan batas wilayah Desa sebagai berikut :

1. Sebelah Utara berbatasan dengan Kelurahan Cisaga Kecamatan Cisaga

2. Sebelah Selatan berbatasan dengan Desa Neglasari Kecamatan Banjar

3. Sebelah Barat berbatasan dengan Desa Cibeureum Kecamatan Banjar

4. Sebelah Timur berbatasan dengan Kelurahan Banjar Kecamatan Banjar Desa Balokang terletak pada ketinggian tempat sekitar $42 \mathrm{mdl}$ dari permukaan laut, dengan dengan curah hujan sekitar 386,40 mm dan mencapai suhu rata-rata harian adalah $27^{\circ}$ Celcius.

\section{Luas Wilayah}

Desa Balokang mempunyai lahan seluas 767 hektar, terdiri dari lahan sawah, ladang, perkebunan dan prasarana umum lainnya. Untuk lebih jelasnya penggunaan lahan di Desa Balokang dapat dilihat pada Tabel 6. 
Tabel 6. Penggunaan Lahan di Desa Balokang Tahun 2019

\begin{tabular}{clrr}
\hline No & $\begin{array}{c}\text { Penggunaan } \\
\text { lahan }\end{array}$ & $\begin{array}{c}\text { Luas } \\
\text { (ha) }\end{array}$ & $\begin{array}{c}\text { Persentase } \\
(\boldsymbol{\%})\end{array}$ \\
\hline 1 & Sawah & 110 & 14,34 \\
2 & Ladang & 301 & 39,24 \\
3 & Perkebunan & 302 & 39,37 \\
4 & Lainnya & 54 & 7,05 \\
\hline & Jumlah & $\mathbf{7 6 7}$ & $\mathbf{1 0 0 , 0 0}$
\end{tabular}

Sumber: Desa Balokang, 2019

Tabel 6 menunjukkan bahwa penggunaan lahan di Desa Balokang Kecamatan Banjar Kota Banjar sebagian besar diperuntukan bagi lahan perkebunan yaitu seluas 302 hektar, sebagian merupakan lahan ladang seluas 301 hektar, lahan sawah seluas 110 hektar dan lahan prasarana lainnya seluas 54 hektar.

\section{Keadaan Penduduk}

Jumlah penduduk merupakan sumberdaya yang sangat potensial dalam pembangunan perekonomian. Berdasarkan data yang tercatat sampai dengan akhir Tahun 2019, jumlah penduduk Desa Balokang tercatat sebanyak 10.795 orang, yang terdiri dari 5.310 orang laki-laki atau
49,18 persendan 5.485 orang perempuan atau 50,82 persen.Keadaan penduduk berdasarkan golongan umur dapat dilihat pada Tabel 7.
Tabel 7. Keadaan Penduduk Desa Balokang Berdasarkan Kelompok Umur

\begin{tabular}{ccrr}
\hline No & $\begin{array}{c}\text { Kelompok } \\
\text { Usia } \\
\text { (Tahun) }\end{array}$ & $\begin{array}{c}\text { Jumlah } \\
\text { Penduduk }\end{array}$ & $\begin{array}{c}\text { Persentase } \\
(\%)\end{array}$ \\
\hline 1 & $0-17$ & 3.248 & 30,08 \\
2 & $18-55$ & 5.854 & 54,22 \\
3 & $>55$ & 1.693 & 16,70 \\
\hline & Jumlah & $\mathbf{1 0 . 7 9 5}$ & $\mathbf{1 0 0 , 0 0}$ \\
\hline
\end{tabular}

Sumber: Desa Balokang, 2019

\section{Keadaan Pendidikan Penduduk}

Pendidikan adalah salah satu faktor yang sangat penting bagi kehidupan seseorang, karena pendidikan ini mempengaruhi mudah tidaknya seseorang menerima hal-hal yang baru. Keadaan penduduk Desa Balokang berdasarkan tingkat pendidikan dapat dilihat pada Tabel 9 sebagai berikut: 
Tabel 9. Keadaan Penduduk Desa Balokang Berdasarkan Tingkat Pendidikan Tahun 2019

\begin{tabular}{lrcc}
\hline No & \multicolumn{1}{c}{$\begin{array}{c}\text { Keadaan } \\
\text { Pendidikan }\end{array}$} & $\begin{array}{c}\text { Jumlah } \\
\text { (orang) }\end{array}$ & $\begin{array}{c}\text { Persentase } \\
(\boldsymbol{\%})\end{array}$ \\
\hline 1 & Taman Kanak-kanak & 119 & 1,46 \\
2 & SD/Sederajat & 3.341 & 41,02 \\
3 & SMP/Sederajat & 1.847 & 22,68 \\
4 & SMA/Sederajat & 2.048 & 25,14 \\
5 & Akademi/D1-D3 & 173 & 2,12 \\
6 & Sarjana (S1) & 582 & 7,14 \\
7 & Sarjana (S2) & 35 & 0,44 \\
\hline & Jumlah & $\mathbf{8 . 1 4 5}$ & $\mathbf{1 0 0 , 0 0}$
\end{tabular}

Sumber: Desa Balokang, 2019

Dari Tabel 9 menunjukkan bahwa tingkat pendidikan responden yang ada di Desa Balokang cukup rendah. Hal ini dapat dilihat dari sebagian besar responden merupakan lulusan SD/sederajat yaitu sebesar 3.341 orang atau 41,02 persen. Rendahnya pendidikan formal di Desa Singajaya Kecamatan Cibalong Kabupaten Tasikmalaya sangat di pengaruhi oleh kondisi ekonomi masyarakat yang kurang mampu, kurang sarana penunjang untuk tingkat pendidikan, masyarakat lebih memilih untuk bekerja dibanding melajutkan pendidikan.

\section{Umur Responden}

Usia adalah faktor yang mempengaruhi terhadap keberhasilan dalam melakukan suatu kegiatan usaha dan juga akan berpengaruh terhadap kemampuan fisik dalam bekerja dan cara berfikir. Berdasarkan hasil penelitian, maka dapat diketahui usia responden dari
Agroindustri Tahu di daerah peneliti berkisar antara 18-55 tahun ke atas.

\section{Tingkat Pendidikan}

Pendidikan formal maupun nonformal adalah salah satu faktor pelancar dalam pembangunan karena dengan pendidikan baik pengetahuan maupun cara berfikir akan bertambah luas. Semakin tinggi tingkat pendidikan yang diperoleh agroindustri tahu, maka semakin luas wawasan pemikirannya sesuai dengan pengetahuan yang diperoleh.Keadaan pendidikan responden dapat dilihat pada Tabel 11 menunjukkan bahwa tingkat pendidikan Perajin Tahu pada umumnya masih tergolong cukup, sebagian besar adalah tamatan Sekolah SD sebanya 6 orang sekitar 70 persen dan yang lainnya merupakan tamatan SMP dan SMA 
Tabel 11. Keadaan Responden Berdasarkan Tingkat Pendidikan

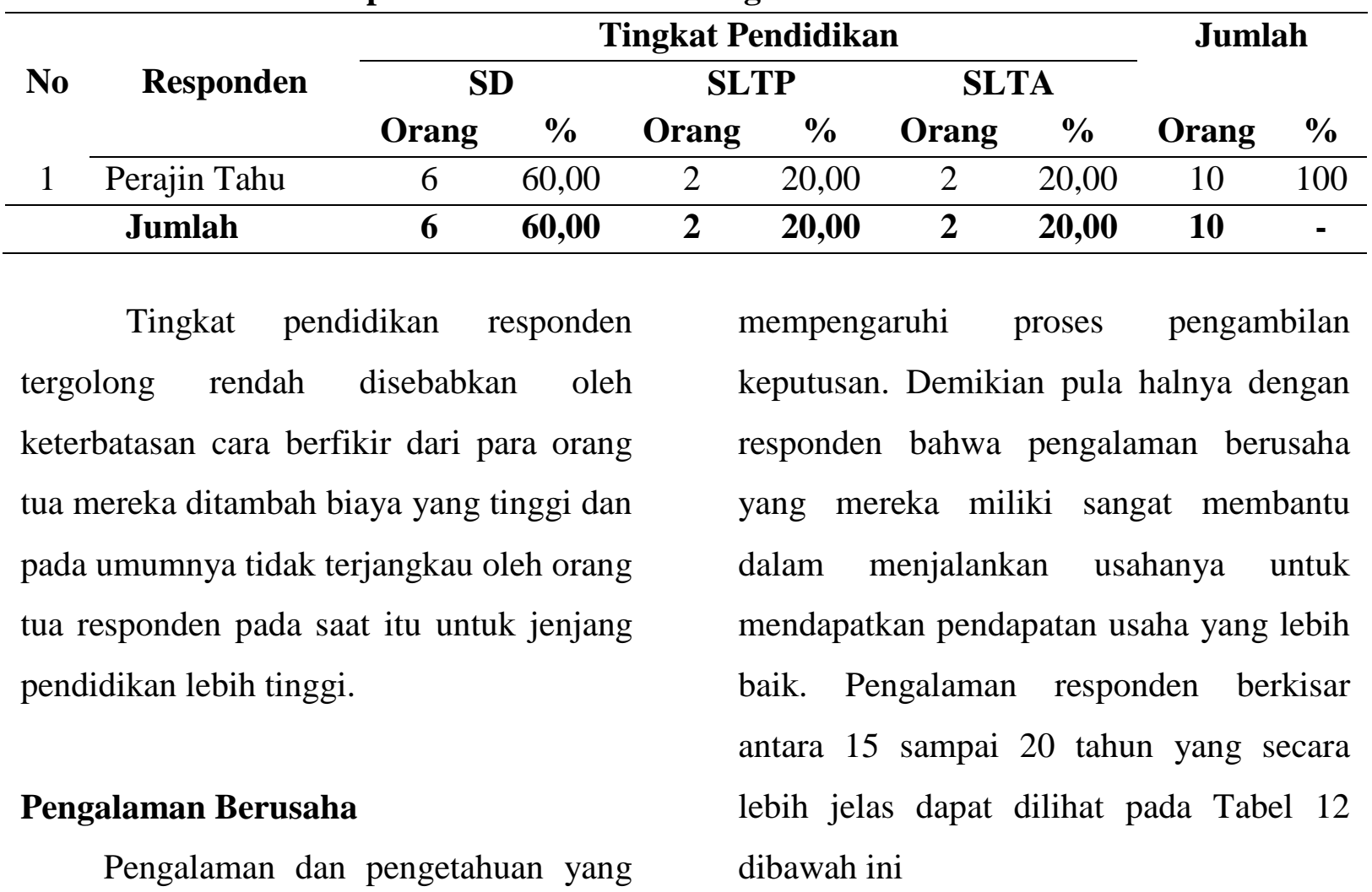

dimiliki seseorang pada umumnya akan

Tabel 12. Keadaan RespondenBerdasarkan Pengalaman Berusaha

\begin{tabular}{|c|c|c|c|c|c|c|c|}
\hline \multirow{3}{*}{ No } & \multirow{3}{*}{ Responden } & \multicolumn{4}{|c|}{ Pengalaman Berusaha } & \multirow{2}{*}{\multicolumn{2}{|c|}{ Jumlah }} \\
\hline & & \multicolumn{2}{|c|}{ 3-11 Th } & \multicolumn{2}{|c|}{$>11 \mathrm{Th}$} & & \\
\hline & & Orang & $\%$ & Orang & $\%$ & Orang & $\%$ \\
\hline 1 & Perajin Tahu & 3 & 75,00 & 1 & 25,00 & 4 & 100 \\
\hline & Jumlah & 3 & 75,00 & 1 & 25,00 & 4 & - \\
\hline
\end{tabular}

\section{Tanggungan Keluarga}

Tanggungan keluarga perajin tahu pada penelitian ini terdiri dari istri, anak, dan anggota keluarga lainnya yang menjadi tanggungan kepala keluarga. Jumlah tanggungan keluarga perajin tahu di Desa Balokang dapat dilihat pada Tabel 13 menunjukkan bahwa sebagian besar perajin tahu memiliki tanggungan rata-rata dibawah 4 atau sekitar 60 persen 
Tabel 13. Keadaan Responden Berdasarkan Jumlah Tanggugan Keluarga

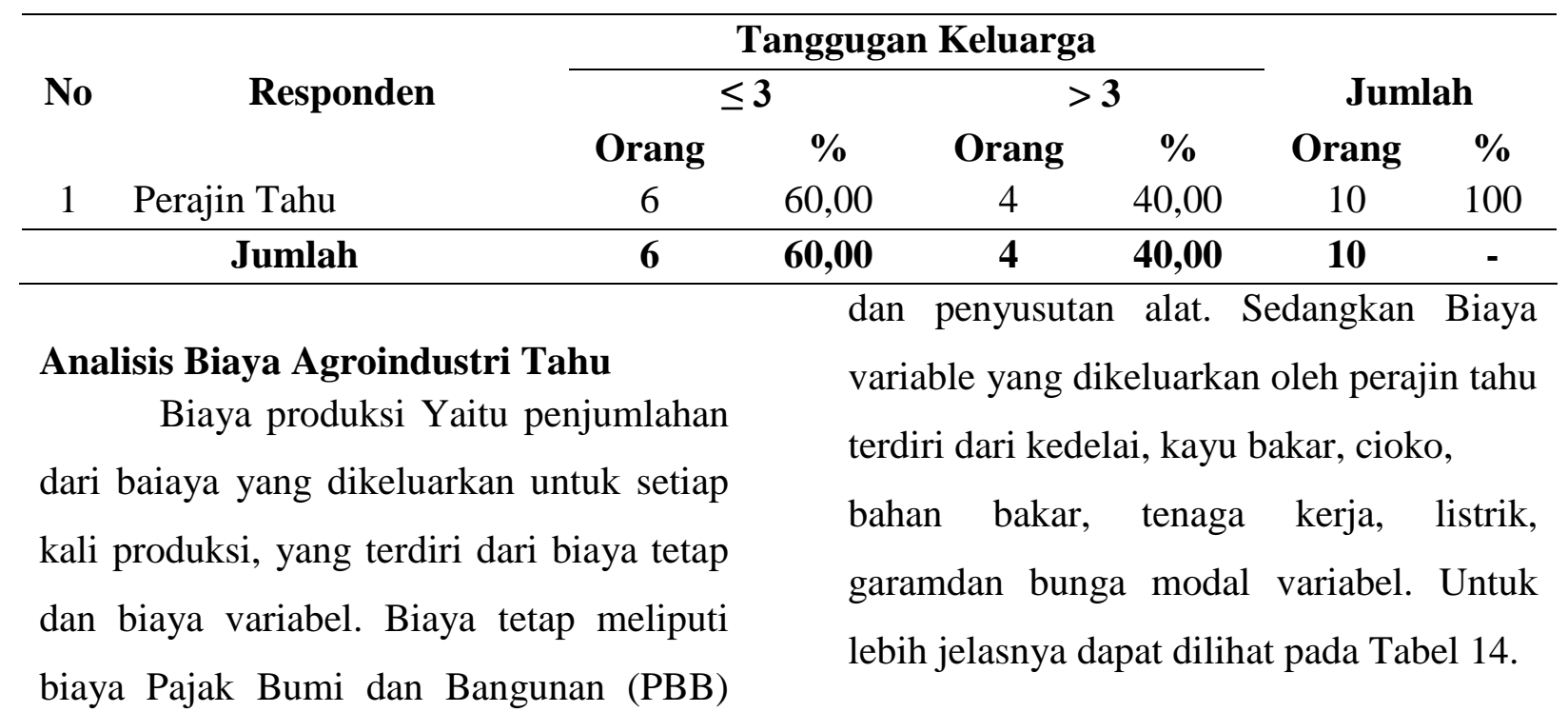

Tabel 14. Rata-rata Biaya Tetap dan Biaya Variabel Agroindustri Tahu per Satu Kali Proses Produksi Di Desa Balokang

\begin{tabular}{|c|c|c|c|}
\hline No & Biaya Tetap & $\begin{array}{c}\text { Besarnya Biaya Tetap } \\
\text { (Rp) }\end{array}$ & $\begin{array}{c}\text { Persentase } \\
(\%)\end{array}$ \\
\hline 1 & Pajak $\quad$ Bumi & 51,82 & 0,30 \\
\hline 2 & Bangunan & $16.942,44$ & 98,90 \\
\hline 3 & $\begin{array}{l}\text { Penyusutan Alat dan } \\
\text { Bangunan } \\
\text { Bunga Modal } \\
\end{array}$ & 135,95 & 0,8 \\
\hline & JUMLAH & $17.130,21$ & 100,00 \\
\hline No & Biaya Variabel & Besarnya Biaya (Rp) & Persentase (\%) \\
\hline 1 & Sarana Produksi & 537.969 & 78,04 \\
\hline 2 & Tenaga Kerja & 146.000 & 21,18 \\
\hline 3 & $\begin{array}{l}\text { Biaya Bunga } \\
\text { Variabel }\end{array}$ & $5.471,75$ & 0,8 \\
\hline & JUMLAH & $689.440,75$ & 100,00 \\
\hline
\end{tabular}

Tabel 14 menunjukkan bahwa jumlah biaya tetap total agroindustri tahu persatu kali proses produksi adalah Rp.16.994,44. Biaya tetap yang paling besar adalah penyusutan alat dan bangunan yaitu Rp.16.994,44 atau 98,90 persen dari biaya total yang dikeluarkan perajin. Adapun penggunaan biaya tetap lainnya yaitu pajak bumi dan bangunan Rp. 51,82 atau 0,30 persen dan bunga modal sebesar Rp 135,95 atau 0,8 persen. Daftar Penyusutan alat dan bangunan, PBB dan bunga modal terlampir.

Sedangkan jumlah biaya variabel total agroindustri tahu persatu kali proses produksi adalah $\mathrm{Rp} 689.440,75$. Biaya variabel yang paling besar adalah biaya sarana produksi yaitu Rp 537.969 atau 
78,04 persen dari biaya total yang dikeluarkan perajin. Adapun penggunaan biaya tenaga kerja Rp 146.000 atau 21,18 persen dan biaya bunga variabel sebesar Rp 5.471,75 atau 0,8 persen. Data Rincian Sarana Produksi terlampir.

\begin{tabular}{|c|c|c|c|}
\hline \multicolumn{4}{|c|}{$\begin{array}{l}\text { Tabel 15. Biaya Total Agroindustri } \\
\text { Tahu dalam Satu Kali Proses } \\
\text { Produksi Di Desa Balokang } \\
\end{array}$} \\
\hline No & Biaya & $\begin{array}{c}\text { Jumlah } \\
\text { (Rp) }\end{array}$ & $\begin{array}{c}\text { Persentase } \\
(\%)\end{array}$ \\
\hline 1 & Biaya & 17.130 & 2,42 \\
\hline \multirow[t]{3}{*}{2} & Tetap & 21 & 97,58 \\
\hline & Biaya & $689.440,75$ & \\
\hline & Variabel & & \\
\hline \multirow{2}{*}{\multicolumn{2}{|c|}{$\begin{array}{l}\text { BIAYA } \\
\text { TOTAL }\end{array}$}} & 706.570,96 & 100,00 \\
\hline & & & \\
\hline
\end{tabular}

Tabel 15 menunjukkan bahwa jumlah biaya tetap per satu kali proses produksi yang dikeluarkan perajin agroindustri tahu adalah sebesar Rp $706.570,96$

\subsubsection{Analisis Penerimaan dan Pendapatan}

Dalam menentukkan berhasil atau tidaknya usaha dapat diukur dari besar kecilnya penerimaan dan pendapatan yang diperoleh. Besarnya penerimaan itu sendiri dipengaruhi oleh harga jual dengan jumlah produksi yang dihasilkan. Penerimaan yang diperoleh perajin agroindustri tahu adalah jumlah tahu yang dihasilkan dikalikan dengan harga tahu per buah yang berlaku pada saat penelitian dan ditambah dengan ampas tahu yang dihasilkan. Rata- rata biaya produksi yang dikeluarkan tiap satu kali proses produksi sebesar Rp 706.570,96 sedangkan dalam satu kali produksi rata-rata mendapat penerimaan sebesar Rp 1.265.000 dengan demikian rata-rata perajin memperoleh pendapatan sebesar Rp 558.429,04 untuk lebih jelasnya biaya produksi, penerimaan dan pendapatan agroindustri tahu di Desa Balokang dapat dilihat pada Tabel 16. Daftar penerimaan hasil produksi terlampir

\begin{tabular}{|c|c|c|}
\hline abel & $\begin{array}{l}\text { 16. Biaya } \\
\text { Penerin } \\
\text { Pendap } \\
\text { Agroinc } \\
\text { Satu K } \\
\text { di Desa }\end{array}$ & $\begin{array}{lr}\text { Rata-Rata } & \text { Total, } \\
\text { aan } & \text { dan } \\
\text { tan } & \text { Usaha } \\
\text { ustri Tahu dalam } \\
\text { li Proses Produksi } \\
\text { Balokang }\end{array}$ \\
\hline No & Uraian & $\begin{array}{c}\text { Jumlah } \\
\text { (Rp) }\end{array}$ \\
\hline 1 & Penerimaan & 1.265 .000 \\
\hline 2 & Biaya Total & $706.570,96$ \\
\hline 3 & Pendapatan & $558.429,04$ \\
\hline
\end{tabular}

\section{Analisis R/C}

$\mathrm{R} / \mathrm{C}$ adalah perbandingan antara penerimaan total dengan biaya produksi total. Rata-rata $\mathrm{R} / \mathrm{C}$ usaha agroindustri tahu di Desa Balokang dapat diketahui dengan rumus sebagai berikut :

$$
\begin{aligned}
R / C & =\frac{\text { rata }- \text { rata penerimaan total }}{\text { rata }- \text { rata biaya total }} \\
& =\frac{1.265 .000}{706.570,96} \\
& =1,79
\end{aligned}
$$

Dari hasil perhitungan diketahui bahwa usaha agroindustri tahu yang ada di Desa 
Balokang memiliki nilai rata-rata $\mathrm{R} / \mathrm{C}$ sebesar 1,79, hal ini menunjukkan bahwa dari setiap satu rupiah biaya yang dikeluarkan, perajin akan memperoleh penerimaan sebesar $\operatorname{Rp} \quad 1,79$ dan pendapatan atau keuntungan sebesar 0,79 rupiah, sehingga dapat dikatakan bahwa usaha agroindustri tahu yang dijalankan perajin adalah menguntungkan karena $\mathrm{R} / \mathrm{C}$ nya lebih dari Rp. 1.

\section{KESIMPULAN DAN SARAN}

\section{Kesimpulan}

Berdasarkan hasil penelitian dan pembahasan maka dapat diambil kesimpulan sebagai berikut :

1. Besarnya biaya produksi rata-rata yang dikeluarkan oleh perajin agroindustri tahu yang berada di Desa Balokang Kecamatan Banjar Kota Banjar adalah sebesar Rp 706.570,96 dan penerimaan rata-rata yang diperoleh perajin sebesar $\mathrm{Rp} \mathrm{Rp}$ 1.265.000 dalam satu kali proses produksi

2. Pendapatan rata-rata yang diperoleh perajin agroindustri tahu sebesar $\mathrm{Rp}$ 558.429,04 dalam satu kali proses produksi.

3. Para perajin usaha agroindustri tahu, apabila dilihat dari segi ekonomis cukup menguntungkan. Hal ini dapat dilihat dari nilai $\mathrm{R} / \mathrm{C}$ sebesar 1,79 artinya setiap $\mathrm{Rp} 1,00$ biaya yang dikeluarkan diperoleh penerimaan sebesar 1,79 dan memperoleh pendapatan atau keuntungan sebesar 0,79 .

\section{Saran}

Dari hasil penelitian dan pembahasan, disarankan bahwa untuk meningkatkan pendapatan para perajin harus menambahkan jumlah produksi, tetapi tidak lepas dari kepandaian perajin untuk mencari pasar yang lebih banyak.

Perajin disarankan aktif dalam mengikuti program peningkatan usaha rakyat, seperti pelatihan, seminar, dan lainlain yang diselenggarakan pemerintah atau lembaga terkait. Karena dengan berperan aktif, maka perajin akan mendapatkan informasi usaha, ilmu pengetahuan, sehingga dapat mengefisiensikan biaya produksi tanpa harus menaikan harga jual produk

\section{DAFTAR PUSTAKA}

Adisarwanto, T. 2005. Budidaya dengan Pemupukan yang Efektif dan Pengoptimalan Peran Bintil Akar Kedelai. Penebar Swadaya. Bogor.

Arikunto, S. 2006. Metode Penelitian Kualitatif. Jakarta: Bumi Aksara

Arixs. 2006. Mengenalkan Olahan Bahan Pangan Nonberas. http://www.cybertokoh.com [16 Maret 2020].

Bantacut, T dan Heruman, H. 2001. Teknis Analisis Prospektif Produksi Industri Bahan.Jakarta : Penerbit Swadaya. 
Baridwan, Zaki. 2009. Sistem Akuntansi Penyusunan Proosedur dan Metode. Yogyakarta : YKPN.

Cahyadi, W. 2007. Kedelai: Khasiat dan Teknologi. Jakarta: Bumi Aksara.

Firdaus, M. 2012. Manajemen Agribisnis. Bumi Aksara. Jakarta.

Hayami, Y. 1987. Agricultural marketing and processing in Upland Java, A Perspektif from a Sunda Village. CGPRT Center. Bogor.

Irwan, A.E. 2006. Budidaya Tanaman Kedelai.

http://pustaka.unpad.ac.id/wpcontent/upload/2009/03/budidayatanaman-kedelai.pdf $\quad[16 \quad$ Maret 2020].

Kotler, Amstrong. 2001. Prinsip-prinsip pemasaran, Edisi keduabelas, Jilid 1. Jakarta: Erlangga .

Kusnandar, Ruli. Cara Cerdas Berkebun Emas. Jakarta : Transmedia Pusaka.

Lupiyoadi dan Hamdani. 2006. Manajemen Pemasaran jasaEdisi kedua. Penerbit Salemba Empat: Jakarta.

Partwijto, A. 2003. Peningkatan Prduksi Sebagai Salah Satu Faktor
Ketahanan Pangan. Jakarta : Majalah Dunia Insinyur.

Sajo, D. 2009. Klasifikasi Industri. http://geografibumi.blogspot.com/20 09/10/ klasifikasi-industri.html [16 Maret 2020].

Sarwon, B dan Saragih, Y.P. 2004. Membuat Aneka Tahu. Jakarta : Penerbit Swadaya.

Soekartawi. 2016. Agribisnis Teori dan Aplikasinya. Jakarta : Rajawali Pers.

Suliantri, dan W.P. Rahayu. Teknologi Fermentasi Umbi-umbian dan Bijibijian. Pusat Antar Universitas Pangan dan Gizi. Institut Pertanian Bogor. Bogor.

Suprapti, M.L. 2005. Pembuatan Tahu. Kanisius. Yogyakarta.

Suprapto, . 2005. Pembuatan Tahu. Ypgyakarta : Penerbit Kanisius.

Swastha, Basu dan Irawan 2011, Manajemen Pemasaran Modern. Yogyakarta: Liberty.

Tjiptono, Fandy., 2005, Manajemen Jasa, Penerbit Andi, Yogyakarta.

Umar, Husein. 2005. Riset Pemasaran dan Perilaku Konsumen. PT.Gramedia Pustaka Utama, Jakarta. 